\title{
Effect of black plastic mulch and raised bed on soil temperature and yield of sweet pepper
}

\author{
Locher, J., Ombódi, A., Kassai, T., Tornyai, T. and Dimény, J. \\ Department of Horticultural Technology, Szent István University, 2103 Gödöllö Páter K. 1., Hungary
}

\begin{abstract}
Summary: A field study was conducted in Central Hungary in 2001 and 2002 in order to evaluate the effects of black plastic mulch and raised bed on soil temperature and on yield and fruit quality of sweet pepper (Capsicum annuum L. cv. 'Kárpia'). The experiment was a complete block design with four replicates. Four different technologies were used as treatments: raised bed with black PE mulch, raised bed without mulch, level ground with black PE mulch and level ground without mulch. In both years soil temperature was the highest in the covered raised bed treatment, about $2{ }^{\circ} \mathrm{C}$ higher than in the uncovered raised bed. Optimum soil temperature requirement of sweet pepper roots was met to the highest degree in case of the covered raised bed, 26-28\% of the total growing period. The more favourable soil temperature conditions resulted in better yield, compared to the uncovered level ground treatment the covered raised bed treatment produced $19 \%$ and $14 \%$ higher yield in 2001 and 2002 , respectively.
\end{abstract}

Key words: Sweet pepper, black plastic mulch, raised bed

\section{Introduction}

The use of plastic films as soil mulches is widespread in horticultural production and is especially common in the production of high value vegetable crops (Waterer, 2000). Plastic mulches are often used in conjunction with raised bed (Bosland \& Votava, 1999).

The advantages of plastic mulches are higher yields, better fruit quality, earlier harvest, better moisture retention, inhibition of weeds, reduced fertilizer leaching, decreased soil compaction, fruit protection from soil deposits and soil microorganisms (Bosland \& Votava, 1999; Lamont, 1993). One of the main objectives in using plastic mulch is the increased soil temperature (Wien \& Minotti, 1987). Root zone temperature is important in plant growth and development because it affects uptake of water and mineral nutrients (Tindall et al., 1990). Raised beds are commonly used to improve soil warming and drainage and to decrease disease incidence (VanDerwerken \& Wilcox-Lee, 1988; Moórné, 2000).

The optimal soil temperature for sweet pepper is according to Somos (1984) $25^{\circ} \mathrm{C}$, and research have shown that from 5 different root-zone temperatures fruit weight was maximum at 24 and $30{ }^{\circ} \mathrm{C}$ (Gosselin \& Trudel, 1986). Because Hungary is situated on the northern border of the open field sweet pepper production zone, soil temperature could be a growth and yield limiting factor in this country.

Raised bed combined with black PE mulch nowadays is gaining more and more importance in Hungary, because open field sweet pepper production can maintain its profitability in the long term just in case of using intensive production technology (plug seedlings, drip irrigation and fertigation, raised bed and plastic mulch) (Moórné, 2002). One of the most important element of the intensive open field sweet pepper growing is the use of plastic films as soil mulches (Lamont, 1993). Many papers were published in international periodicals about the use of plastic mulch and raised bed in sweet pepper production, and although there are many examples for the use of this technology on considerable area in Hungary, there are very few Hungarian researches done in this field.

The objective of this research was to evaluate the effects of black plastic mulch combined with raised bed and level ground on soil temperature, fruit quality and yield of sweet pepper under Hungarian climatic circumstances.

\section{Material and method}

Two experiments were conducted in 2001 and 2002 at Gödöllổ, at latitude of $47,61^{\circ}$ and longitude of $19.32^{\circ}$, on loamy sand soil. The cultivar used was the kapia-type Kárpia $\mathrm{F}_{1}$.

The experimental design was both year a complete block with four treatments and four replications. The treatments were raised bed with black PE mulch, raised bed without mulch, level ground with black PE mulch, and level ground without mulch. The black polyethylene mulch was $0.12 \mathrm{~mm}$ thick and in $20011.5 \mathrm{~m}$ and $0.75 \mathrm{~m}$ wide, and in $20021.5 \mathrm{~m}$ and $1 \mathrm{~m}$ wide in the case of raised bed and level ground, respectively.

Raised beds were $0.9 \mathrm{~m}$ wide at the base and $0.25 \mathrm{~m}$ high, and were situated in north-south direction. Before lying the mulches drip irrigation line $(0.10 \mathrm{~m}$ emitter spacing) was 
placed on the surface of the soil in the centre of the bed. Plants were seeded into a peat-fruit compost mix in seedling trays ( $4 \times 4-\mathrm{cm}$ cell size) in the first week of April. Sixweek-old pepper seedlings $(40$ plants/plot $)$ were transplanted, two rows per bed, $0.3 \mathrm{~m}$ between rows and 0.25 between plants $\left(5.7\right.$ plants $\left./ \mathrm{m}^{2}\right)$ on 16 May 2001 and 15 May 2002.

Fertigation was done through the drip irrigation system 1 to 3 times per week. Time of irrigation was determined by soil matric potential monitored by tensiometers. Fruits were harvested on five occasions during the growing season (in 2001 at Aug. 27, Sept. 6, Sept. 19, Oct. 4, Oct. 17; in 2002 at Aug. 13, Aug. 28, Sept. 10, Sept. 25, Oct. 7). At every harvest time weight and number of the fruits per plot were recorded, and the average fruit weight, as the most important quality characteristic in Hungary, was calculated.

Soil temperature was measured hourly with MIKUNI TR-71S thermorecorders. The temperature sensors were placed at $10 \mathrm{~cm}$ depth under the plant row on the west side of the raised bed, halfway between two plants. The soil temperature was recorded at hourly interval from 26 May in 2001 and 17 May in 2002 until the end of the growing period. This measurement was done in one replication in 2001 and in all the four replications in 2002. In 2001 there were some short interruptions in the measurement because of technical problems.

\section{Results and discussion}

Soil temperature. Soil temperature in the average of the whole growing season for both years are shown in Table 1. In both years average soil temperatures were higher in the covered treatments than in the uncovered treatments. In 2002. the difference was statistically significant in case of both raised bed and level ground. Between the two uncovered treatments the difference was neglectable in both years. On the other hand, there was significant difference between the two mulched treatments, in favour of the favour of the raised bed. In both years, average soil temperature was the highest in the covered raised bed treatment, while it was the lowest in the uncovered raised bed and in the uncovered level ground in 2001 and 2002, respectively. In case of raised bed, mulch covering caused an increase with about $2{ }^{\circ} \mathrm{C}$ in the average soil temperature compared to the level ground. For the level ground treatments this increase was less $\left(0.5-1.1^{\circ} \mathrm{C}\right)$. This difference was presumably caused by the bigger surface of the raised bed.

Table 1 contains some additional soil temperature characteristics, which were determined from the measured data. Naturally, tendency of sum of daily average temperatures was similar to that of the average soil temperature. In both years, absolute minimum temperatures were the lowest in the uncovered raised bed, and the highest in the covered level ground treatment and in the covered raised bed treatment, in 2001 and in 2002, respectively. The absolute maximum temperature was the highest in the covered raised bed treatments in both years.

We also calculated that how many percent of the measured data belonged in the optimal temperature range of the sweet pepper root. On the basis of the data of Somos (1984) and Gosselin \& Trudel (1986) we took the range $24^{\circ} \mathrm{C}-30^{\circ} \mathrm{C}$ as the optimal one. Optimum soil temperature requirement was met to the highest degree in the covered raised bed treatment, along the $26 \%$ and $28 \%$ of the total growing period in 2001 and 2002, respectively (Figure 1). In 2002, this ratio was almost two times higher of that for the uncovered level ground treatment. In all treatments, suboptimal temperatures had the highest and supraoptimal temperatures had the lowest ratio, underlining the necessity of soil temperature raising among Hungarian_field growing conditions.

Figure 2 shows that for all treatments soil temperature was the warmest between 17 and 19 o'clock and the coolest between 7 and 8 o'clock. Soil night-time temperatures were higher in the mulched treatments because the air gap between the mulch and soil reduces convective heat transfer; the plastic trapped a portion of the outgoing long wave radiation emitted from the soil, and the plastic layer prevented evaporative cooling (Ham et al, 1993). It is visible that difference in soil temperature between the corresponding level ground and raised bed treatments had developed during daytime.

Figure 3 shows the seasonal trend of root-zone temperature. Throughout the whole growing period rootzone temperature was the highest in the covered raised bed treatment. This treatment was especially superior during the early growing period, when the foliage did not shadowed the surface in great degree. From the end of August until the end of the growing period soil temperature declined gradually from about $17{ }^{\circ} \mathrm{C}$ to $9{ }^{\circ} \mathrm{C}$, for all treatments. At the end of

Table $I$ Effect of black plastic mulch and raised bed on some characteristics of soil and on temperature characteristics $10 \mathrm{~cm}$ below the soil surface

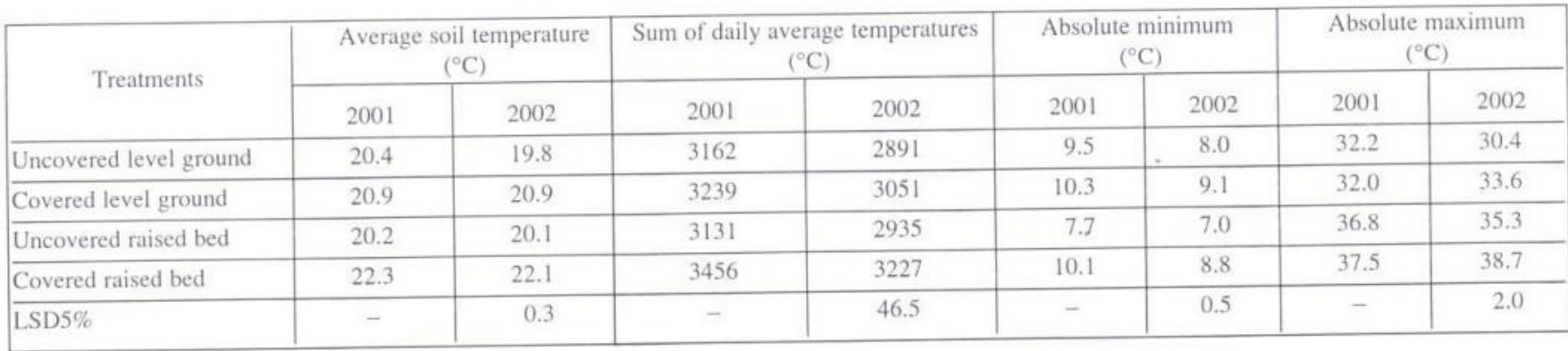


$\square$ suboptimal $<24^{\circ} \mathrm{C}$ a optimal $24-30^{\circ} \mathrm{C}$ supraoptimal $>30^{\circ} \mathrm{C}$
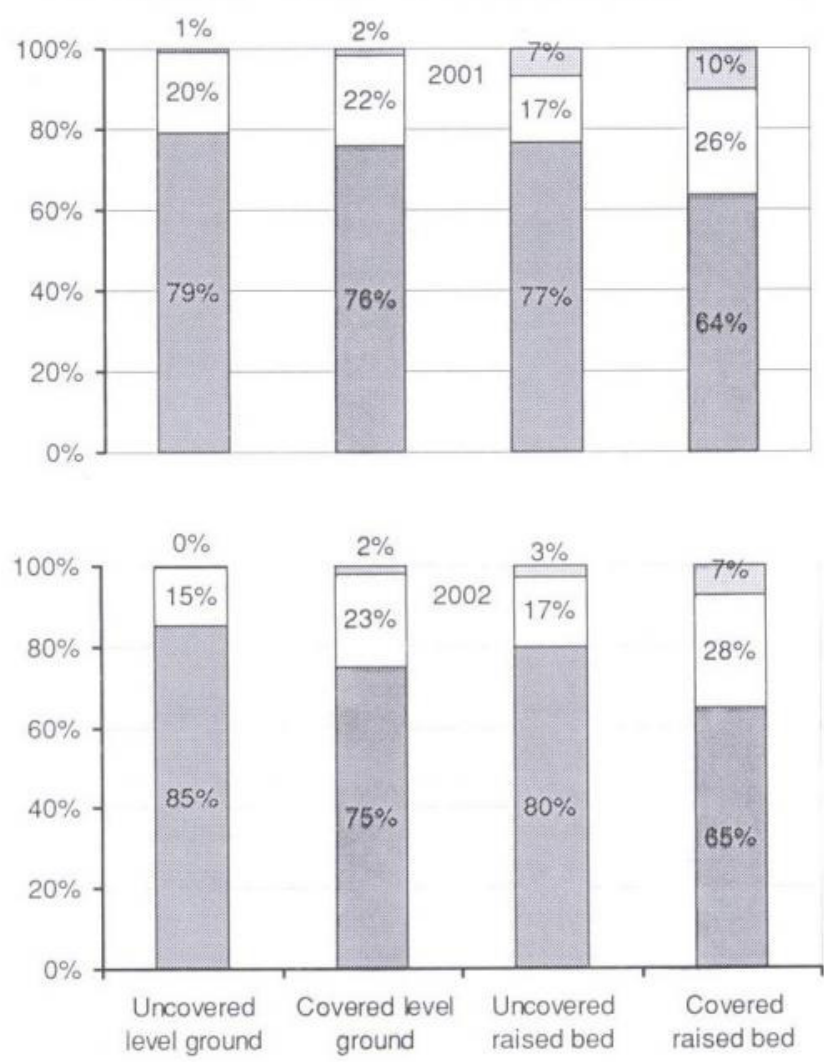

Figure 1 The percentual distribution of optimal, suboptimal and supraoptimal temperature values for field grown sweet pepper in different treatments

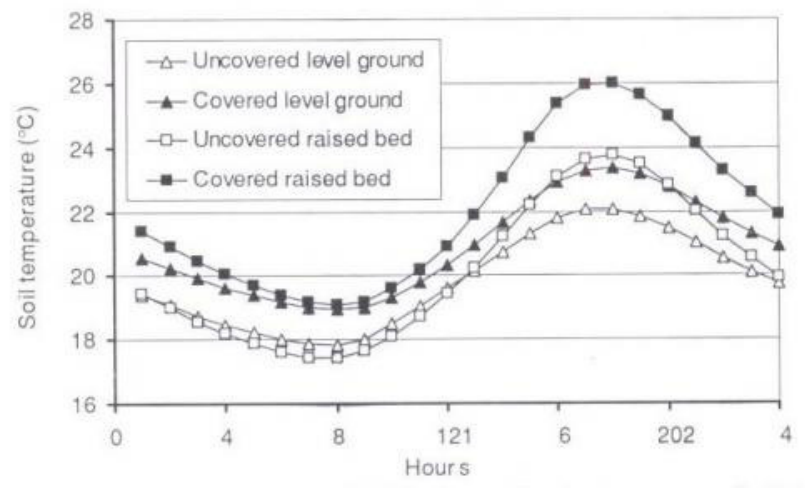

Figure 2 Diurnal trends in root-zone temperatures in the average of the whole growing season in 2002

(Each symbol represents the hourly mean RZT for the whole season.)

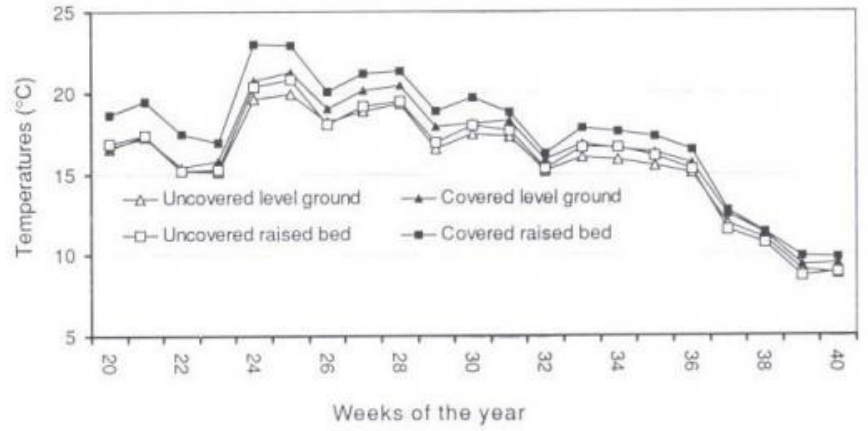

Figure 3 Seasonal trend of root-zone temperature during growing season in 2002.

(Each symbol represents the weekly mean RZT in case of each treatments.)

the growing season (from the $36^{\text {th }}$ week) the difference among the treatments was neglectable because of the low air temperatures.

Yield and average fruit weight. Yields of marketable fruits were significantly the highest in the covered raised bed treatment in both years. In 2002 the covered level ground treatment also produced significantly better yield than the uncovered raised bed treatment. In 2001 in the covered raised bed treatment the average fruit weight was significantly higher than in the uncovered level ground treatment, but there were no significant differences among treatments for fruit number per $\mathrm{m}^{2}$. Treatments had no significant effect on average fruit weight, however the covered treatments produced significantly more fruit per $\mathrm{m}^{2}$ than the uncovered treatments that year. According to our opinion main reason of the significantly higher yields in the covered raised bed treatment was the more favourable root zone temperature conditions in that treatment.

In our experiment the main advantage of using plastic soil mulch, its soil warming effect, was justified. In both years the mulched treatments warmed up better than the unmulched treatments. In the covered raised bed treatment root zone temperature was about $2{ }^{\circ} \mathrm{C}$ higher than in the uncovered raised bed. This result is in good agreement with the result of Lamont (1993), who found $1.7^{\circ} \mathrm{C}$ soil increase in soil temperature at 10 $\mathrm{cm}$ depth caused by covering with black plastic mulching. In case of level ground, mulch covering caused just $1{ }^{\circ} \mathrm{C}$ increase in root zone temperature, and in the covered raised bed treatment the average soil temperature was $1.3^{\circ} \mathrm{C}$ higher than in the covered level ground treatment. Raised bed warmed up

Table 2 Effects of black plastic mulch and raised bed on marketable fruit yield, average fruit weight and fruit number of sweet pepper

\begin{tabular}{|c|c|c|c|c|c|c|}
\hline \multirow{2}{*}{ Treatments } & \multicolumn{2}{|c|}{ Yield $(\mathrm{kg} / \mathrm{m} 2)$} & \multicolumn{2}{|c|}{ Average fruit weight (g) } & \multicolumn{2}{|c|}{ Fruit number (pieces/ m2) } \\
\hline & 2001 & 2002 & 2001 & 2002 & 2001 & 2002 \\
\hline Uncovered level ground & 3.15 & 4.60 & 62 & 91 & 54 & 58 \\
\hline Covered level ground & 3.38 & 4.95 & 63 & 87 & 55 & 65 \\
\hline Uncovered raised bed & 3.47 & 4.43 & 64 & 92 & 57 & 353 \\
\hline Covered raised bed & 3.92 & 5.35 & 67 & 89 & 58 & 64 \\
\hline LSD5\% & 0.38 & 0.38 & 4 & 5 & 6 & 6 \\
\hline
\end{tabular}


better because its bigger surface could absorb more radiation and that is why difference in soil temperature between the two treatments developed mainly during daytime. Differences in soil temperature among the treatments were higher during the beginning of growing period when the foliage of the plants did not shadow the surface considerably. During the last 5 weeks of the growing period temperature differences among the treatments became neglectable because of less radiation reaching the surface due to less solar radiation and bigger plant foliage. Optimum soil temperature requirement was met to the highest degree in the covered raised bed treatment, $26 \%$ and $28 \%$ of the total growing period in 2001 and 2002, respectively. In this experiment by using black PE mulch covered raised bed technology $19 \%$ and $14 \%$ higher marketable yield was achieved than in the generally used uncovered level ground treatment.

Based on these results we concluded that the raised bed combined with black PE mulch produced the significantly higher yield due to the favourable soil temperature conditions achieved in that treatment.

\section{References}

Bosland, P.W. \& Votava, E.J. (1999): Peppers: vegetable and spice capsicum. CAB International, Wallingford UK.
Gosselin, A. \& Trudel, M.J. (1986): Root-zone temperature effects on pepper. J. Amer. Soc. Hort. Sci. 111(2): 220-224.

Ham, J. M., Kluitenberg, G.J. \& Lamont, W.J. (1993): Optical properties of plastic mulches affect the field temperature regime. J. Amer. Soc. Hort. Sci. 118(2): 188

Lamont, Jr., W.J. (1993): Plastic mulches for production of vegetable crops. Hort Technology, 3: 35-39.

Moórné (2000): A sikeres paprikatermesztés néhány technológiai eleme. (Some elements of the successful pepper growing technology. In Hungarian) Hajtatás, korai termesztés, 3: 7-8.

Moórné (2002): Szabadföldi paprikatermesztés (Open field sweet pepper production. In Hungarian). Termó-Föld, 3(3): 10-11.

Somos, A. (1984): A paprika (The Pepper). Akadémiai Kiadó, Budapest.

Tindall, J.A., Mills, H.A. \& Radcliffe, D.E. (1990): The effect of root-zone temperature on nutrient uptake of tomato. J. Plant Nutr. 13: 939-956.

Vanderwerken, J.E. \& Wilcox-Lee, D. (1988): Influence of plastic mulch and type and frequency of irrigation on growth and yield of bell pepper. HortScience, 23: 985-988.

Waterer, D.R. (2000): Effect of soil mulches and herbicides on production economics of warm season vegetable crops in a cool climate. Hort Technology. 10: 154-159.

Wien, H.C. \& Minotti, P.L. (1987): Growth, yield and nutrient uptake of transplanted fresh-market tomatoes as affected by plastic mulch and initial nitrogen rate. J. Amer. Soc. Hort. Sci. 112: 759-763. 